\title{
VENTRICULAR MURAL THROMBUS IN PATIENT WITH LEFT VENTRICULAR ANEURYSM AFTER MYOCARDIAL INFARCTION
}

\author{
Makharynska O. S. , Lisogorska O. V. ${ }^{2}$, Oktiabrova I. I. ${ }^{1}$, Adu Albert Asare ${ }^{1}$ \\ ${ }^{1}$ V. N. Karazin Kharkiv National University, Kharkiv, Ukraine \\ ${ }^{2}$ Kharkiv city clinical multi-field hospital No 25, Kharkiv, Ukraine
}

On the example of the clinical case of newly diagnosed mural thrombus in patient with post ST-elevation myocardial infarction chronic aneurysm formation, probable risk of further tromboembolism and anticoagulation benefit was discussed. Recommendations on lifestyle modification and medicament treatment tactics are described for prevention of new mural thrombi formation.

KEY WORDS: STEMI, mural thrombus, anticoagulation, risk, ventricular aneurism

\section{ПРИСТІНКОВИЙ ТРОМБ У ПАЦІЕНТА ІЗ АНЕВРИЗМОЮ ЛІВОГО ШЛУНОЧКА ПІСЛЯ ПЕРЕНЕСЕНОГО ІНФАРКТУ МІОКАРДА 3 ЕЛЕВАЦІЕЮ SТ-СЕГМЕНТУ}

\author{
Махаринська О. С. ${ }^{1}$, Лісогорська О. В. ${ }^{2}$, Октябрьова I. I. ${ }^{1}$, Аду Альберт Асаре \\ ${ }^{1}$ Харківський національний університет імені В. Н. Каразіна, м. Харків, Україна \\ 225 міська клінічна багатопрофільна лікарня, м. Харків, Україна
}

На прикладі клінічного випадку вперше діагностованого пристінкового тромбу у пацієнта 3 аневризмою лівого шлуночка після перенесеного інфаркту міокарда 3 елевацією ST-сегменту обговорили можливий ризик подальших тромбоемболічних ускладнень і переваги антикоагулянтної терапії. Описано рекомендації з модифікації способу життя і тактики лікування для запобігання утворення нових пристінкових тромбів.

КЛЮЧОВІ СЛОВА: STEMI, пристінковий тромб, антикоагулянтна терапія, ризик, шлуночкова

\section{ПРИСТЕНОЧНЫЙ ТРОМБ У ПАЦИЕНТА С АНЕВРИЗМОЙ ЛЕВОГО ЖЕЛУДОЧКА ПОСЛЕ ПЕРЕНЕСЕННОГО ИНФАРКТА МИОКАРДА С ЭЛЕВАЦИЕЙ ऽТ-СЕГМЕНТА}

Махаринская Е. С. ${ }^{1}$, Лисогорская Е. В. ${ }^{2}$, Октябрева И. И. ${ }^{1}$, Аду Альберт Асаре

${ }^{1}$ Харьковский национальный университет имени В. Н. Каразина, г. Харьков, Украина

${ }^{2} 25$ городская клиническая многопрофильная больница, г. Харьков, Украина

На примере клинического случая впервые диагностированного пристеночного тромба у пациента с развившейся постинфарктной аневризмой после перенесенного инфаркта миокарда с ST- элевацией обсудили вероятный риск дальнейших тромбоэмболических осложнений и преимуществ антикоагулянтной терапии. Описаны рекомендации по модификации образа жизни и тактике лечения для предотвращения образования новых пристеночных тромбов.

КЛЮЧЕВЫЕ СЛОВА: STEMI, пристеночный тромб, антикоагулнтная терапия, риск, аневризма желудочка

\section{INTRODUCTION}

Left ventricular (LV) thrombus formation is a frequent complication in patients with acute anterior myocardial infarction (MI), occurring in at least $5 \%$ of patients. Left ventricular thrombus is associated with increased risk of embolism. [1]. In the context of STEMI, prolonged ischemia results in subendocardial and endothelial injury and increased concentration of procoagulant factors, whereas akinetic areas of necrotic myocardium lead to blood stasis, especially at the LV apex [2]. Two-dimensional transthoracic echocardiography is the most effective diagnostic technique in this setting and can be quickly performed at the bedside but can lead to misdiagnoses due to difficult echo windows, 
artifact, or the misinterpretation of $\mathrm{LV}$ trabeculations or chordae. [3]. In a recent article by Wada et al [4] was demonstrated the excellent diagnostic power of echo contrast for the diagnosis of LV thrombus in 392 patients with anterior MI. Echo contrast had $100 \%$ sensitivity and specificity compared with left ventriculography and/or multidetector computed tomography used as gold standard [5]. Anticoagulation therapy reduces both risks of thrombus formation and subsequent embolization, but leads to increased risk of bleeding. [6] Therefore, accurate detection and exclusion of $\mathrm{LV}$ thrombus in patients with coronary artery disease (CAD) are very important [7]. In observational studies and meta-analyses, anticoagulant therapy is recommended in order to minimize embolization risk. An oral vitamin $\mathrm{K}$ antagonist, warfarin, has been being used as an anticoagulant for this purpose for a long period of time. New oral anticoagulants (dabigatran, rivaroxaban, apixaban, etc.) were found to be non-inferior or superior compared to warfarin in prevention of thromboembolism in patients with nonvalvular atrial fibrillation [8].

\section{CLINICAL CASE}

A 72-year old man was admitted by ambulance in the emergency department of 25 Kharkiv city clinical multi-field hospital with complains on anxiety, general weakness, trembling inside, palpitation periodically, dyspnea and chest pain after mild physical activity.

\section{ANAMNESIS MORBI}

Diagnosis of arterial hypertension (AH) and coronary artery disease were established 20 years ago (in 1993 patient had acute anteriorlateral myocardial infarction). Usual blood pressure levels by patient's words are 170/90 100, he receives constant therapy with angiotensin-converting enzyme inhibitors (ACEIb). Also patients receive constant therapy with aspirin $75 \mathrm{mg} /$ day around 5 years long. This time he felt worse 3 days before hospitalization, when appeared palpitation, trembling inside and anxiety, increased general weakness. Was administered by ambulance in cardiology department of 25 city hospital.

\section{ANAMNESIS VITAE}

Childhood infections, injuries, tuberculosis, sexually transmitted diseases were denied by patient. Hereditary diseases are not identified. Allergic history is burdened (penicillin). Smoking - denied, not an alcohol abuser.

\section{OBJECTIVE EXAMINATION}

Conciseness - clear, state - moderate severe, body position - active. Patient can orientate himself in place, time, his personality. Pale skin and mucosae. Thyroid: not enlarged, soft. Musculoskeletal system - no changes. Breathe rate - 16-18/min. Lung percussion: no clinically significant changes. Lung auscultation: hard breathing. Borders of the heart: left border - outside of midclavicular left line on $2 \mathrm{~cm}$. Heart auscultation: arrhythmic, extrasystoles $2-3$ in min, heart tones - muffled, diastolic soft murmur over apex. Pulse arrhythmic, $76 \mathrm{bts} / \mathrm{min}$. Blood pressure 145/80 mm Hg. Abdomen: normal size, symmetric, unpainful. Liver: normal size, no pain during palpation in right hypochondrium. Spleen: normal. Pasternatsky symptom negative from both sides. Edemas: absent. In admitting office, preliminary diagnosis was: Coronary Arteries Disease: post-MI (1993) atherosclerotic cardiosclerosis. Arterial hypertension III stage, III degree, very high risk. Ventricular extrasystolic arrhythmia. Chronic Heart Failure IIA stage, III functional class by NYHA.

\section{LABORATORY AND INSTRUMENTAL TESTS}

Complete blood count data from 09-oct2017: no clinically important changes, all other parameters within normal limits. Urinalysis: all parameters within normal limits. In biochemistry analysis data significant were: abnormal level ALS $0,80 \quad(0,1-$ $0,445 \mathrm{mkmol} / \mathrm{h} * \mathrm{ml})$ and AST $0,98 \quad(0,1-$ $0,68 \mathrm{mkmol} / \mathrm{h} * \mathrm{ml})$. Lipid profile showed dyslipidemia with elevated concentrations of total cholesterol till 6.03 (normal ranges $-<$ $5.2 \mathrm{mmol} / \mathrm{l}$ ), lipoproteins of low density till $4,19 \mathrm{mmol} / 1(\mathrm{~N}-<3.5)$, lipoproteins of high density till $1,49 \mathrm{mmol} / \mathrm{l}(\mathrm{N}-<0.9)$, index of atherogenicity was 3,37 within normal limits 3.0. Patient didn't take any constant hypolipidemic therapy before hospitalization. ECG during admit ion showed sinus rhythm, HR 98 bts, ventricular extrasystolic arrhythmia, classical for chronic aneurism ST-elevation without dynamics in antero-lateral leads V2-V5 leads with $\mathrm{T}$-wave inversion. In our patient chest X-ray was found enlargement of heart 
shadow to the left, aorta with sclerotic changes and no mediastinum enlargement seen. Echocardiography was also made: Aorta: dilated, capsids are thickened. Ascending aorta - d 38 (20-37 mm). Aortic regurgitation I degree. Tricuspid valve - no regurgitation. Pulmonary trunk valve - no regurgitation. Pressure in pulmonary trunk is $19,0 \mathrm{~mm} \mathrm{Hg}$ $(<15)$. Mitral valve - capsids are moderately thickened, movements of leaflets is in different direction, anterior capsid in left atrium cavity during systole, regurgitation II degree. Ejection fraction $(\mathrm{EF})-36 \%(\mathrm{~N}-55-78 \%)$. Function of contractility $-41 \%(\mathrm{~N}-28-44 \%)$. Left Ventricle: FDD - $53 \mathrm{~mm}(\mathrm{~N}-35-55 \mathrm{~mm})$, FSD - $42 \mathrm{~mm}(\mathrm{~N}-23-38 \mathrm{~mm})$, posterior wall thickness in systole- 12,2 $\mathrm{mm}(\mathrm{N}-6-3 \mathrm{~mm})$. Intraventricular septum size in diastole6,0 $\mathrm{mm}(6-11 \mathrm{~mm})$. Additional chorda in LV cavity. In LV cavity situated round shape parietal thrombus $27 * 29 \mathrm{~mm}$. Right Ventricle: diameter $-28,1 \mathrm{~mm}(\mathrm{~N}-9-26 \mathrm{~mm})$, wall thickness $-6,0 \mathrm{~mm}(\mathrm{~N}-3-6 \mathrm{~mm})$. Left atrium - enlarged - 44,1 $\mathrm{mm}$ in diameter $(\mathrm{N}$ - till $38 \mathrm{~mm}$ ). Right atrium - not enlarged, $36 \mathrm{~mm}(\mathrm{~N}$ - 25-37). Interatrial septum - not changed, no defects. Conclusion: Sclerotic changes of aorta. Aortic regurgitation I degree. Mitral regurgitation II degree. Akinesia of LV apical segments and intraventricular septum with diastolic dysfunction of LV. Moderate dilation of left atrium. Chronic heart aneurism of LV with mural thrombus.

Abdominal ultrasound performed: Liver: Right lobe - 131 (N-till $150 \mathrm{~mm}$ ), left lobe thickness - 64 (N-till $65 \mathrm{~mm}$ ), moderate echogenicity, structure is homogenous. Ductular system is not changed. Gall bladder: $43 * 19 \mathrm{~mm}$. Wall thickness is increased, normal shape. Pancreas: head - $27 \mathrm{~mm}(\mathrm{~N}-24$ $30 \mathrm{~mm})$, tail - $26 \mathrm{~mm}(\mathrm{~N}-17-28)$, body $24 \mathrm{~mm}$ ( N - 12-17). Increased parenchyma echogenicity, homogenous. Ductular system is not changed. Spleen: $76 * 27 \mathrm{~cm}$. Normal echogenicity, structure is homogenous. Right kidney: $90 * 45 \mathrm{~mm}$, parenchyma $-17 \mathrm{~mm}$, moderate echogenicity, structure is homogenous, not changed, microlithiasis. Left kidney: $91 * 49 \mathrm{~mm}, \mathrm{~V}=84 \mathrm{~cm} / \mathrm{c}$, parenchyma $16 \mathrm{~mm}$, normal echogenicity, structure is homogenous, enlarged due to pelvis dilation. Conclusion: Diffuse changes and fibrosis of pancreas parenchyma. Calculous kidney disease. Left sided pyeloectasia.

\section{FINAL DIAGNOSIS}

Coronary Artery Disease: stable angina III functional class, postinfarction cardiosclerosis (1993). Chronic heart aneurism with mural thrombus. Mitral regurgitation II degree, aortic regurgitation I degree. Arterial Hypertension III degree, III stage, very high risk. Ventricular extrasystolic arrhythmia. HAS-BLED Score - 3 points. Chronic Heart Failure IIIC stage with left ventricle systolic dysfunction (EF - 36\%), III functional class by NYHA. Chronic pancreatitis. Chronic pyelonephritis, microlithiasis.

\section{TREATMENT RECEIVED IN HOSPITAL}

Perindopril $4 \mathrm{mg} 1$ timelday from admission, nebivolol 2,5 $\mathrm{mg} 1$ time/day from admission, rosurvastatin $10 \mathrm{mg} 1$ time a day from admission, aspirin $100 \mathrm{mg} 1$ time daily from admission, fondaparinux $2,5 \mathrm{mg}$ subcutaneously from admission, tiotriazolin (metabolic) $4,0 \mathrm{ml}$ IV 1 timelday from admission.

\section{RECOMMENDATIONS}

Summarizing data from 2017 ESC Guidelines for the management of acute myocardial infarction in patients presenting with STsegment elevation [9] and 2016 ESC Guidelines for the diagnosis and treatment of acute and chronic heart failure [10], the following may be applicable for our patient after discharge from hospital and for prevention of further mural thrombi formation and thromboembolic episodes appearance:

1. For mural thrombi, once diagnosed, oral anticoagulant therapy should be considered for up to 6 months, guided by repeated echocardiography and with consideration of bleeding risk and need for concomitant antiplatelet therapy [11].

2. Secondary mitral valve regurgitation: LV remodeling with lateral and apical displacement of the papillary muscles, leaflet tethering, and annular dilatation are a common cause of secondary (functional) mitral regurgitation. While transthoracic echocardiography is fundamental for the initial diagnosis, transesophageal echocardiography may be needed for better definition of the mechanism and severity of mitral regurgitation. The severity of mitral regurgitation may improve with reperfusion and aggressive medical treatment, including diuretics and arterial 
vasodilators. In our patients case can be treated symptomatically without surgical correction needed [9].

3. ACE-blockers is recommended and should be up-titrated to the maximum tolerated dose, in addition to a beta-blocker, for symptomatic patients with $\mathrm{CHF}$ with reduced ejection fraction (HFrEF) to reduce the risk of HF hospitalization and death. A beta-blocker is recommended initially at a low dose with gradually up-titration to the maximum tolerated dose, in addition an ACE-Id or ARB if ACEIb is not tolerated or contraindicated, for patients with stable, symptomatic HFrEF to reduce the risk of HF hospitalization and death. Betablockers are also effective agents for angina control in our patient's case [10].

4. Mineralocorticoid/aldosterone receptor antagonists are recommended in all symptomatic patients (despite treatment with an
ACEI and a beta-blocker) with HFrEF and $\mathrm{LVEF} \leq 35 \%$. Can be avoided in our patient case as $\mathrm{EF}$ is $36 \%$, but used as $\mathrm{AH}$ treatment as needed $[9,11]$.

\section{CONCLUSIONS}

Left ventricular thrombus is an important complication of acute myocardial infarction that impacts embolic event risk and anticoagulant therapy. Improved understanding of post-MI thrombus in the current era is critical for optimization of diagnostic testing strategies. Advances in MI management, including prompt and effective coronary reperfusion, have yielded improvements in LV function and remodeling. Widespread use of antiplatelet agents may potentiate the benefits of reperfusion, thereby lessening the likelihood of LV thrombus.

\section{REFERENCES}

1. Okuyan E. Risk factors for development of left ventricular thrombus after first acute anterior myocardial infarction-association with anticardiolipin antibodies / [E. Okuyan, B. Okcun, et al.] // Thrombosis Journal. - 2010. - No. 8. - p. 8-15.

2. Delewi R. Left ventricular thrombus formation after acute myocardial infarction. / R. Delewi, F. Zijlstra, J. J. Piek // Heart. - 2012. - No. 98. - p. 1743-1749.

3. Gianstefani S. Incidence and Predictors of Early Left Ventricular Thrombus After ST-Elevation Myocardial Infarction in the Contemporary Era of Primary Percutaneous Coronary Intervention / [S. Gianstefani, A. Douiri, et al.] // http://dx.doi.org/10.1016/j.amjcard.2013.12.015

4. Wada H. Contrast echocardiography for the diagnosis of left ventricular thrombus in anterior myocardial infarction. / [H. Wada, T. Yasu, K. Sakakura, et al.] // Heart Vessels. - 2013, [e-pub ahead of print].

5. Kurt M. Impact of contrast echocardiography on evaluation of ventricular function and clinical management in a large prospective cohort. / [M. Kurt, K. A. Shaikh, L. Peterson, et al.] // J Am Coll Cardiol. - 2009. - No. 53. - p. 802-810.

6. Kontny F. Randomized trial of low molecular weight heparin (dalteparin) in prevention of left ventricular thrombus formation and arterial embolism after acute anterior myocardial infarction: the Fragmin in Acute Myocardial Infarction (FRAMI) Study. / [F. Kontny, J. Dale, U. Abildgaard, et al.] // J Am Coll Cardiol. 1997. -No. 30. - p. 962-969.

7. Monvadi B.S. Clinical, imaging, and pathological characteristics of left ventricular thrombus: A comparison of contrast-enhanced magnetic resonance imaging, transthoracic echocardiography, and transesophageal echocardiography with surgical or pathological validation. / [B. S. Monvadi, J. Chelif, et al.]. // American Heart Journal. - 2006. - No. 151 (1). - p. 75-84.

8. Yildirim E. Successful resolution of left ventricular thrombus with apixaban treatment. / [E. Yildirim, K. Kalkan, E. Ipek, et al.]. // International Journal of the Cardiovascular Academy. - 2016. - No. 2. p. $57-58$.

9. 2017 ESC Guidelines for the management of acute myocardial infarction in patients presenting with STsegment elevation / [B. Ibanez, S. James, S. Agewall, et al.] // European Heart Journal. - 2017. - p. 1-66.

10.2016 ESC Guidelines for the diagnosis and treatment of acute and chronic heart failure / [P. Ponikowski, A. Adriaan, et all.] // European Heart Journal. - 2016. - p. 1-85.

11.2017 ESC Guidelines for the management of acute myocardial infarction in patients presenting with STsegment elevation - Web Addenda / [B. Ibanez, S. James, S. Agewall, et al.] // European Heart Journal. 2017. - p. 1-8. 